\title{
ANALISIS KANDUNGAN LOGAM ZINK (Zn) DANTIMBAL (Pb) DALAM AIR LAUT PESISIR PANTAI MAMBORO KECAMATAN PALU UTARA
}

\author{
Content Analysis of Zinc ( $\mathrm{Zn})$ and Lead (Pb) Metals on the Sea Water in \\ Mamboro Coastal Marine North Palu
}

\author{
* Tatik Rahmadani, Sri Muliyani Sabang, dan Irwan Said \\ Pendidikan Kimia/FKIP - Universitas Tadulako, Palu - Indonesia 94118 \\ Received 13 September 2015, Revised 12 October 2015, Accepted 11 November 2015
}

\begin{abstract}
This study aims to determine concentration of zinc $(\mathrm{Zn})$ and lead $(\mathrm{Pb})$ metals on the sea water in coastal areas Mamboro District of North Palu. The method used was a spectrophotometry using Atomic Absorption Spectrophotometer (AAS). Seawater samples were taken from three different points, is A (5 meter), $B$ (10 meter), and C (15 meter) within $\pm 5 \mathrm{~m}$ from the coastline, and sampling started from the edge of the harbor of cooking oil companies. Results of the analysis of zinc contents from the three points are $0.155 \mathrm{mg} / \mathrm{L}$ at point $A, 0.126 \mathrm{mg} / \mathrm{L}$ at point $B$, and $0.109 \mathrm{mg} / \mathrm{L}$ at point $C$, respectively. Moreover, the lead contents are $0.35 \mathrm{mg} / \mathrm{L}$ at point $A, 0.391 \mathrm{mg} / \mathrm{L}$ at point $B$, and $0.433 \mathrm{mg} / \mathrm{L}$ at point $C$, respectively. Concentration of zinc metal on the sea water in Mamboro Coastal Marine ranged from $0.109 \mathrm{mg} / \mathrm{L}-0.155 \mathrm{mg} / \mathrm{L}$, which is higher than the threshold value zinc metal, $0.01 \mathrm{mg} / \mathrm{L}$, where concentration of lead metal on the sea water in Mamboro Coastal Marine ranged from $0.35 \mathrm{mg} / \mathrm{L}-$ $0.433 \mathrm{mg} / \mathrm{L}$, which is higher than the threshold value of lead metal, $0.025 \mathrm{mg} / \mathrm{L}$.
\end{abstract}

Keywords: Zinc $(\mathrm{Zn})$ and lead $(\mathrm{Pb})$, sea water, Atomic absorption spectrophotometer (AAS).

\section{Pendahuluan}

Seiring dengan perkembangan zaman dan kemajuan teknologi sekarang ini, dapat juga memicu perkembangan industri yang semakin pesat. Semakin banyaknya industri yang berkembang seperti saat ini dapat memberi pengaruh buruk bagi lingkungan, khususnya lingkungan laut yang kebanyakkan orang memilih laut sebagai tempat akhir pembuangan limbah industri. Limbah-limbah yang masuk ke wiliyah perairan laut dapat memicu terjadinya pencemaran laut (Bozkurt, dkk., 2014). Keberadaan logam berat di perairan laut dapat berasal dari berbagai sumber, antara lain dari kegiatan pertambangan, rumah tangga, limbah pertanian dan buangan industri (Rochyatun, dkk., 2006). Limbah-limbah pencemar dapat mengakibatkan banyaknya kandungan logam berat pada air laut, hal ini akan berdampak buruk bagi kelangsungan ekosistem laut dan juga bagi mahluk hidup lainnya, khususnya

*Correspondence:

Tatik Rahmadani

Program Studi Pendidikan Kimia, Fakultas Keguruan dan

IImu Pendidikan, Universitas Tadulako

email: tatik_rahmadanidhanie@yahoo.co.id

Published by Universitas Tadulako 2015 manusia (Suprapti, dkk., 2012).

Laut Indonesia memiliki luas lebih kurang 5,6 juta $\mathrm{km} 2$ dengan garis pantai sepanjang $81.000 \mathrm{~km}$, dengan potensi sumberdaya, terutama perikanan laut yang cukup besar (Ika, 2012). Nampak bahwa kepentingan pembangunan ekonomi di Indonesia lebih memanfaatkan potensi sumberdaya daratan daripada potensi sumberdaya perairan laut. Perkembangan IPTEK memacu terjadinya pencemaran lingkungan baik pencemaran air, tanah maupun udara. Pencemaran air yang diakibatkan oleh dampak perkembangan industri harus dapat dikendalikan, karena bila tidak dilakukan sejak dini akan menimbulkan permasalahan yang serius bagi kelangsungan hidup manusia maupun alam sekitarnya (Herman, 2006). Logam berat umumnya bersifat racun terhadap makhluk hidup walaupun beberapa diantaranya diperlukan dalam jumlah kecil (Begum, dkk., 2009). Melalui berbagai perantara, seperti udara, makanan, maupun air yang terkontaminasi oleh logam berat, logam tersebut dapat terdistribusi ke bagian tubuh manusia dan sebagian akan terakumulasikan. Jika keadaan ini berlangsung secara terus-menerus, dalam jangka waktu lama 
dapat mencapai jumlah yang membahayakan kesehatan manusia (Ruslan, 2008).

Sulawesi Tengah dalam hal ini khususnya perairan laut Mamboro, memegang peranan penting dalam menunjang kebutuhan hidup dari sebagian masyarakat, yang paling umum adalah berupa kebutuhan ikan serta adanya budidaya rumput laut yang dapat meningkatkan pendapatan bagi sebagian masyarakat terutama nelayan. Sementara itu di wilayah pantai Mamboro terdapat dua jenis perusahaan yang memperoleh bahan baku dengan menggunakan transportasi laut. Kegiatan tersebut membuat banyaknya aktivitas kapal yang berlalulalang di daerah perairan yang ada di Mamboro, aktivitas yang terjadi bukan hanya bongkar muat bahan baku yang akan digunakan tetapi juga penggantian bahan bakar minyak oleh kapalkapal yang bersandar. Logam berat timbal yang terkandung dalam bahan bakar kendaraan laut ini dapat memicu tingginya kadar logam berat timbal dalam air laut (Sudarmaji, dkk., 2006). Selain itu juga adanya aktivitas warga masyarakat yang tinggal di sekitar perairan yang dapat memicu tercemarnya air laut. Yakni aktivitas warga yang terbiasa membuang limbah rumah tangga melalui sampah-sampah metabolik dan korosi pipa-pipa air yang mengandung logamlogam berat juga dapat memberikan dampak yang cukup besar terhadap masuknya logamlogam berat ke perairan laut Mamboro.

Semakin banyaknya aktivitas masyarakat tersebut di perairan maka tidak menutup kemungkinan juga akan bertambahnya kadar logam berat dalam air laut (Hamzah \& Saputro, 2013). Dengan adanya aktivitas-aktivitas tersebut dapat diperkirakan bahwa perairan laut Mamboro telah mengalami perubahan kondisi alamiahnya. Pencemaran logam berat merupakan permasalahan yang sangat serius untuk ditangani, karena merugikan lingkungan dan ekosistem secara umum (Bangun, 2005). Logam berat terbagi atas dua jenis yakni logam berat esensial dan non esesnsial. Jenis yang pertama yakni logam berat esensial yang sangat dibutuhkan setiap makhluk hidup, namun beberapa di antaranya (dalam kadar tertentu) bersifat racun. Unsur ini di alam biasanya terdapat dalam bentuk terlarut atau tersuspensi (terikat dengan zat padat) serta terdapat sebagai bentuk ionik. Contoh dari logam berat untuk unsur esensial adalah Zn. Keberadaan logam zink (Zn) dalam air laut bersumber dari penggunaan pupuk kimia yang mengandung logam $\mathrm{Cu}$ dan $\mathrm{Zn}$, buangan limbah rumah tangga yang mengandung logam $\mathrm{Zn}$ seperti korosi pipa-pipa air dan produk-produk konsumer (misalnya, formula detergen) yang tidak diperhatikan sarana pembuangannya (Tarigan, dkk., 2003). Sedangkan untuk jenis kedua adalah logam berat non esensial atau beracun, di mana keberadaannya dalam tubuh masih belum diketahui manfaatnya atau bahkan bersifat racun seperti logam timbal $(\mathrm{Pb})$. Secara alamiah timbal dapat masuk ke dalam lingkungan perairan melalui pengkristalan timbal di udara dengan bantuan air hujan. Di samping itu proses pelapukan dari batuan mineral akibat hempasan gelombang dan angin juga merupakan salah satu jalur sumber timbal yang masuk ke lingkungan perairan (Fismawati, 2010).

Ika (2012) telah melakukan penelitian mengenai analisis logam timbal $(\mathrm{Pb})$ dan besi $(\mathrm{Fe})$ dalam air laut di wilayah pesisir pelabuhan ferry Taipa kecamatan Palu Utara. Aanalisis ini dilakukan dengan menggunakan alat spektrofotometer serapan atom (SSA). Hasil yang diperoleh dari penelitian ini ialah untuk konsentrasi logam timbal $(\mathrm{Pb})$ berkisar antara $0,703 \mathrm{mg} / \mathrm{L}-0,919 \mathrm{mg} / \mathrm{L}$. Konsentrasi tersebut lebih tinggi jika dibandingkan dengan NAB logam timbal yaitu $0,025 \mathrm{mg} / \mathrm{L}$ dan untuk konsentrasi logam besi $(\mathrm{Fe})$ berkisar antara $0,324 \mathrm{mg} / \mathrm{L}-0,546 \mathrm{mg} / \mathrm{L}$, konsentrasi tersebut lebih tinggi jika dibandingkan dengan NAB logam besi yaitu $0,01 \mathrm{mg} / \mathrm{L}$.

Logam berat yang masuk ke perairan, baik di sungai maupun lautan dipindahkan dari badan airnya melalui tiga proses yaitu pengendapan, adsorbsi, dan absorbsi oleh organisme-organisme perairan (Siaka, 2008). Pada saat buangan limbah industri masuk ke dalam suatu perairan maka akan terjadi proses pengendapan dalam sedimen (Marasabessy, dkk., 2010). Hal ini menyebabkan konsentrasi bahan pencemar dalam sedimen meningkat. Logam berat yang masuk ke dalam lingkungan perairan mengalami pengendapan, pengenceran dan dispersi, kemudian diserap oleh organisme yang hidup di perairan tersebut. Pengendapan logam berat di suatu perairan terjadi karena adanya anion karbonat hidroksil dan klorida (Siaka, 2008). 
Laut juga mempunyai arti penting bagi kehidupan mahluk hidup seperti manusia, ikan, tumbuh-tumbuhan, dan biota laut lainnya. Hal ini menunjukkan bahwa sektor lautan mempunyai potensi yang sangat besar untuk dapat ikut mendorong pembangunan di masa kini maupun masa depan. Oleh karena itu, laut yang merupakan suatu sumber daya alam yang sangat perlu untuk dilindungi. Hal ini berarti pemanfaatannya harus dilakukan dengan bijaksana dengan memperhitungkan kepentingan generasi sekarang dan yang akan datang (Ika, 2012). Tulisan ini dimaksudkan untuk memberikan gambaran kandungan dari logam zink $(\mathrm{Zn})$ dan timbal $(\mathrm{Pb})$ yang ada dalam air laut pesisir pantai Mamboro Kecamatan Palu Utara.

\section{Metode}

Peralatan yang digunakan yaitu seperangkat alat SSA spektra AA 932, botol berwarna gelap, labu ukur, gelas ukur, gelas kimia, pipet tetes, pipet volum, karet penghisap, $\mathrm{pH}$ meter, botol semprot, corong dan kertas label. Sedangkan bahan yang digunakan yaitu air lait, aquades, asam nitrat $\left(\mathrm{HNO}_{3} 69 \%\right.$ ) smart lab, $\mathrm{Pb}\left(\mathrm{NO}_{3}\right)_{2}$ Riedel-de haen, $\mathrm{ZnSO}_{4} .7 \mathrm{H}_{2} \mathrm{O}$ merck, $\mathrm{HNO}_{3} 1$ $\mathrm{M}$ smart lab, $\mathrm{NH}_{4} \mathrm{OH} 1 \mathrm{M}$ merck dan kerta saring.

\section{Cara Kerja}

Pengambilan sampel air laut dilakukan pada pagi hari dengan 3 titik tempat pengambilan sampel yaitu pada jarak $\pm 5 \mathrm{~m}, 10 \mathrm{~m}$ dan $15 \mathrm{~m}$, yang berjarak $\pm 5 \mathrm{~m}$ dari garis pantai dan pengambilan dimulai dari tepi dermaga pelabuhan perusahaan minyak goreng. Sampel air laut diambil dengan menggunakan botol berwarna gelap, yang berukuran $150 \mathrm{~mL}$ kemudian sampel air laut tersebut ditambahkan sebanyak 5 tetes larutan asam nitrat $\left(\mathrm{HNO}_{3}\right)$ $65 \%$. Sederet larutan standar zink dan timbal 0 ppm; 0,05 ppm; 0,1 ppm; 0,5 ppm; 1,0 ppm; 1,5 ppm; dan 2 ppm dilihat dari larutan induknya. Kemudian terhadap deret ini, diukur serapannya pada panjang gelombang $217 \mathrm{~nm}$ untuk logam timbal dan pada panjang gelombang 213,9 nm untuk logam zink. Setelah itu dibuatkan kurva kalibrasi untuk kedua logam tersebut. kemudian sampel air laut diambil sebanyak $10 \mathrm{~mL}$ kemudian
pHnya di atur sampai 5 lalu dianalisis dengan Spektrofotometer Serapan Atom pada panjang gelombang $217 \mathrm{~nm}$ untuk logam timbal dan panjang gelombang 213,9 $\mathrm{nm}$ untuk logam zink (Ika, 2012).

\section{Analisa Data}

Berdasarkan hasil pengukuran yang diperoleh menggunakan alat Spektrofotometer Serapan Atom (SSA), maka data yang diperoleh dapat dihitung menggunakan persamaan (Kacaribu, 2008).

$$
y=a+b x
$$

\section{Hasil dan Pembahasan}

Tabel 1. Data analisis zink ( $\mathrm{Zn}$ ) pada larutan standar dengan menggunakan alat SSA.

\begin{tabular}{|clcc|}
\hline No & Nama & $\begin{array}{c}\text { Konsentrasi } \\
(\mathrm{ppm})\end{array}$ & Absorbansi \\
\hline 1. & Blangko & 0 & $-0,002$ \\
2. & Standar 1 & 0,05 & 0,006 \\
3. & Standar 2 & 0,1 & 0,018 \\
4. & Standar 3 & 0,5 & 0,085 \\
5. & Standar 4 & 1 & 0,130 \\
6. & Standar 5 & 1,5 & 0,240 \\
7. & Standar 6 & 2 & 0,304 \\
\hline
\end{tabular}

Tabel 2. Data analisis zink ( $\mathrm{Zn}$ ) pada sampel air laut

\begin{tabular}{|c|c|c|c|c|c|}
\hline \multirow{2}{*}{ No } & \multirow{2}{*}{ Sampel } & \multirow{2}{*}{ konsentrasi } & \multicolumn{2}{|c|}{ absorbansi } & \multirow{2}{*}{ Rata-rata } \\
\hline & & & I & II & \\
\hline 1. & Sampel A & 0,155 & 0,024 & 0,023 & 0,0235 \\
\hline 2. & Sampel B & 0,126 & 0,019 & 0,019 & 0,019 \\
\hline 3. & Sampel C & 0,109 & 0,016 & 0,017 & 0,0165 \\
\hline
\end{tabular}

Keterangan : Sampel A = air laut jarak 5 meter; sampel $\mathrm{B}=$ air laut jarak 10 meter; dan sampel $\mathrm{C}=$ air laut jarak 15 meter

Konsentrasi logam zink (Zn) pada Sampel

Konsentrasi pada suatu sampel dapat ditentukan dengan menggunakan persamaan : $y=a+b x$. Konsentrasi logam zink ( $Z n)$ yang diperoleh dapat dilihat pada tabel 1 dan tabel 2 .

\section{Konsentrasi logam timbal (Pb) pada Sampel}

Konsentrasi pada suatu sampel dapat ditentukan dengan menggunakan persamaan : $\mathrm{y}=\mathrm{a}+\mathrm{bx}$. Konsentrasi logam timbal $(\mathrm{Pb})$ yang diperoleh dapat dilihat pada tabel 3 dan tabel 4 . 
Tabel 3. Data analisis timbal $(\mathrm{Pb})$ pada larutan standar dengan menggunakan alat SSA.

\begin{tabular}{llcc}
\hline No & Nama & $\begin{array}{c}\text { Konsentrasi } \\
(\mathrm{ppm})\end{array}$ & Absorbansi \\
\hline 1. & Blangko & 0 & $-0,002$ \\
2. & Standar 1 & 0,05 & 0,002 \\
3. & Standar 2 & 0,1 & 0,003 \\
4. & Standar 3 & 0,5 & 0,012 \\
5. & Standar 4 & 1 & 0,018 \\
6. & Standar 5 & 1,5 & 0,036 \\
7. & Standar 6 & 2 & 0,048 \\
\hline
\end{tabular}

Tabel 4. Data analisis timbal $(\mathrm{Pb})$ pada sampel air laut

\begin{tabular}{lccccr}
\hline \multirow{2}{*}{ No } & \multirow{2}{*}{ Sampel } & konsentrasi & \multicolumn{2}{c}{ absorbansi } & \multirow{2}{*}{ Rata-rata } \\
\cline { 4 - 5 } & & & I & II & \\
\hline 1. & Sampel A & 0,35 & 0,008 & 0,007 & 0,0075 \\
2. & Sampel B & 0,391 & 0,009 & 0,008 & 0,0085 \\
3. & Sampel C & 0,433 & 0,009 & 0,010 & 0,0095
\end{tabular}

Keterangan : Sampel A = air laut jarak 5 meter; sampel $\mathrm{B}=$ air laut jarak 10 meter; dan sampel $\mathrm{C}=$ air laut jarak 15 meter

Logam berat memiliki kriteria yang sama dengan logam-logam lainnya, hanya saja perbedaannya terletak pada pengaruh yang diakibatkan bila logam ini masuk ke dalam tubuh organisme hidup (Rochyatun, dkk., 2006). Logam berat biasanya dapat menimbulkan efek-efek khusus pada tubuh mahluk hidup. Meskipun semua logam berat dapat mengakibatkan keracunan pada mahluk hidup, namun sebagian dari logam berat tersebut tetap dibutuhkan dalam jumlah tertentu (Marasabessy, dkk., 2010).

Wilayah Sulawesi Tengah khususnya Palu banyak dikelilingi oleh perairan, baik perairan air tawar maupun perairan air asin. Dengan banyaknya perairan yang mengelilingi wilayah ini maka kekayaan ekosistem baik dari perairan air tawar maupun asin sangat melimpah dan juga membuat banyaknya aktivitas masyarakat di perairan, baik yang untuk menangkap ikan atau yang lainnya. Perairan juga banyak dimanfaatkan sebagian masyarakat sebagai tempat pembuangan sampah, baik sampah organik maupun anorganik. Dengan banyaknya sampah-sampah yang dibuang ke wilayah perairan dapat membuat perairan tersebut tercemar, khususnya oleh logam-logam berat.
Wilayah perairan yang dengan mudah tercemar oleh logam-logam berat ialah wilayah perairan air asin. Analisis kandungan logam berat dalam air laut ini dapat dianalisis dengan metode spektrofotometri menggunakan alat spektrofotometer serapan atom. Dalam hal ini sampel air laut diambil dengan perbedaan titik pengambilan sampel, yakni menggunakan tiga titik. Titik A pada jarak 5 meter, titik B pada jarak 10 meter, dan titik $C$ pada jarak 15 meter dengan cara pengambilan pada jarak $\pm 5 \mathrm{~m}$ dari garis pantai dan pengambilan dimulai dari tepi dermaga pelabuhan perusahaan. Selanjutnya sampel tersebut ditetesi dengan larutan $\mathrm{HNO}_{3} 65 \%$. Tujuan ditambahkannya larutan tersebut ialah karena larutan $\mathrm{HNO}_{3} 65 \%$ dapat berfungsi sebagai pengawet. Selanjutnya sampel tersebut di bawa ke laboratorium untuk selanjutnya dianalisis. Sebelum menganalisis sampel tersebut, terlebih dahulu membuat larutan standar baik untuk logam zink atau pun timbal. Dan selanjutnya diteruskan dengan membuat deret kerja dengan perbedaan konsentrasi masing-masing. Sebelum dianalisis sampel terlebih dahulu diatur pHnya dengan ditetesi dengan larutan $\mathrm{HNO}_{3} 1 \mathrm{M}$ dan $\mathrm{NH}_{4} \mathrm{OH} 1 \mathrm{M}$.

Hasil perhitungan konsentrasi untuk logam zink $(\mathrm{Zn})$ dalam sampel air laut yang dianalisis menggunakan alat spektrofotometer serapan atom yaitu; titik A pada jarak 5 meter adalah $0,155 \mathrm{mg} / \mathrm{L}$, titik B pada jarak 10 meter adalah 0,126 , dan yang terakhir untuk titik $C$ pada jarak 15 meter adalah 0,109 mg/L. Perbandingan mengenai konsentrasi kandungan logam seng dapat dilihat pada Gambar 1.

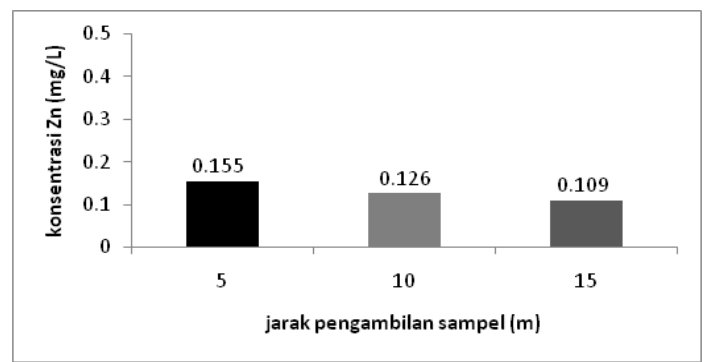

Gambar 1. Grafik konsentrasi logam seng pada tiga titik yang berbeda.

Berdasarkan gambar 1 di atas terlihat bahwa kadar zink pada air laut di wilayah tersebut berkisar antara $0,109 \mathrm{mg} / \mathrm{L}-0,155 \mathrm{mg} / \mathrm{L}$, sehingga dapat diketahui bahwa air laut tersebut telah tercemar oleh logam zink. Merujuk pada nilai ambang batas (NAB) untuk kandungan logam zink pada perairan laut sebesar 0,01 $\mathrm{mg} / \mathrm{L}$ (Effendi, 2003). 
Logam zink ini banyak digunakan dalam bahan baterai. Zink dalam bentuk oksida digunakan untuk industri kosmetik (mencegah kulit agar tidak kering dan tidak terbakar sinar matahari), plastik, karet, sabun, pigmen warna putih dalam cat dan tinta $(\mathrm{ZnO})$, zink dalam bentuk sulfida digunakan sebagai pigmen fosfor serta untuk industri tabung televisi dan lampu pendar. Zink dalam bentuk klorida digunakan sebagai deodoran dan untuk pengawetan kayu, zink sulfat untuk mordan (pewarnaan), stiptik (untuk mencegah pendarahan), sebagai supply zink dalam makanan hewan serta pupuk, sebagai pelapisan cat khususnya dalam industri automobil, dan sebagai bahan dindinglantai logam untuk bahan insektisida dapur (Maslukah, 2006). Pencemaran yang terjadi diperairan laut sekitar mamboro ini terjadi karena banyaknya kapal-kapal yang berlalu lalang, karena seng juga termasuk sebagai bahan pembuatan cat pada kapal dan juga pipa-pipa, seng juga sebagai bahan dalam pembuatan shampo anti ketombe, yakni zinc pyrithione dan zink sulfate dan juga pada formula deterjen yang mana banyaknya limbah air buangan mandi dan mencuci yang mengalir langsung masuk ke perairan laut.

Konsumsi zink ( $\mathrm{Zn})$ dalam jumlah besar atau lebih dapat menyebabkan muntah, diare, demam, kelelahan yang sangat, anemia, dan gangguan reproduksi (Deswati, dkk., 2013). Beberapa ikan dapat terakumulasi zink dalam tubuhnya, ketika ikan tersebut tinggal di wilayah perairan yang sudah terkontaminasi oleh zink. Zink ini tidak selamanya bersifat toksik, karena zink dalam jumlah tertentu dibutuhkan oleh tubuh, zink ditemukan juga pada iris, retina, hepar, pankreas, ginjal, kulit, otot, testis dan rambut, sehingga kekurangan zink berpengaruh pada jaringan-jaringan tersebut (Begum, dkk., 2009). Di dalam darah zink terutama terdapat dalam sel darah merah, sedikit ditemukan dalam sel darah putih, trombosit dan serum.

Hasil perhitungan konsentrasi untuk logam timbal $(\mathrm{Pb})$ dalam sampel air laut yang dianalisis menggunakan alat spektrofotometer serapan atom yaitu; titik A pada jarak 5 meter adalah $0,35 \mathrm{mg} / \mathrm{L}$, titik B pada jarak 10 meter adalah 0,391 , dan yang terakhir untuk titik C pada jarak 15 meter adalah 0,433 $\mathrm{mg} / \mathrm{L}$. Perbandingan mengenai konsentrasi kandungan logam timbal dapat dilihat pada Gambar 2.

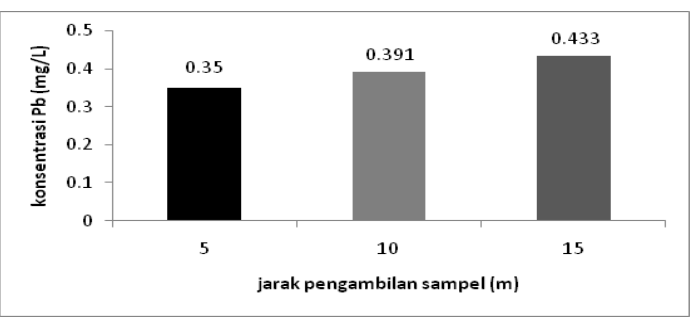

Gambar 2. Grafik konsentrasi logam timbal pada tiga titik yang berbeda.

Berdasarkan gambar 2 diatas dapat terlihat bahwa kadar timbal pada air laut diwilayah tersebut berkisar antara $0,35 \mathrm{mg} / \mathrm{L}-0,433$ $\mathrm{mg} / \mathrm{L}$, sehingga dapat diketahui bahwa air laut tersebut telah tercemar oleh logam timbal. Merujuk pada nilai ambang batas (NAB) untuk kandungan logam timbal pada perairan laut 0,025 mg/L (Effendi, 2003).

Logam timbal merupakan salah satu bahan untuk pencampuran pada pembuatan bahan bakar sebagai anti pemecah minyak (seperti $\mathrm{Pb}$ tetraethyl dan tetramethyl) (Stancheva, dkk., 2013). Lokasi tempat pengambilan sampel, selain banyak dilalui oleh kapal-kapal yang merupakan penyumbang terbesar untuk pencemaran logam timbal, ada juga aktivitas manusia lainnya disekitar perairan yakni perbengkelan, serta pengikisan batuan mineral. Dampak yang dapat terjadi bagi manusia ialah dapat mengakibatkan penghambatan sistem pembentukkan hemoglobin $(\mathrm{Hb})$ sehingga menyebabkan anemia, terganggunya sistem syaraf pusat dan tepi, sistem ginjal, sistem reproduksi, idiot pada anak-anak, cacat rangka dan juga dapat merusak sel-sel somatik (Rahman, 2006).

Pencemaran yang terjadi dalam suatu perairan khususnya pencemaran oleh logamlogam berat dapat menimbulkan banyak masalah baik yang bersifat sementara atau yang bekepanjangan. Pencemaran ini dapat dikurangi dan juga ditanggulangi, ada beberapa cara yang dapat dilakukan diantaranya dengan mengurangi penggunaan zat-zat berbahaya dan menjaga kebersihan lingkungan, maka kelangsungan hidup yang ada di darat maupun di perairan akan terjaga. Penanganan untuk pencemaran logam berat juga dapat menggunakan tumbuhan yang mampu menyerap logam berat, salah satu tumbuhan yang digunakan tersebut adalah pohon api-api (Avicennia marina) (Amriani, 2011). Upaya penanganan pencemaran logam berat sebenarnya dapat dilakukan juga dengan menggunakan proses kimiawi (Sudarmaji, dkk., 
2006). Seperti penambahan senyawa kimia tertentu untuk proses pemisahan ion logam berat atau dengan resin penukar ion (exchange resins), serta beberapa metode lainnya seperti penyerapan menggunakan karbon aktif, electrodialysis dan reverse osmosis. Namun proses ini relatif mahal dan cenderung menimbulkan permasalahan baru, yaitu akumulasi senyawa tersebut dalam sedimen dan organisme akuatik (perairan). Penanganan logam berat dengan mikroorganisme atau mikrobia, menjadi alternatif yang dapat dilakukan untuk mengurangi tingkat keracunan elemen logam berat di lingkungan perairan. Metode atau teknologi ini sangat menarik untuk dikembangkan dan diterapkan, karena memiliki kelebihan dibandingkan dengan proses kimiawi. Serta, lebih baik dari proses pengendapan (presipitation) kalau dikaitkan dengan kemampuan menstimulasikan perubahan $\mathrm{pH}$ dan konsentrasi logam beratnya. Dengan kata lain, penanganan logam berat dengan mikroorganisme relatif mudah dilakukan, murah dan cenderung tidak berbahaya bagi lingkungan (Ni'matuzahroh, dkk., 2006).

Masalah pencemaran laut ini tidak bisa diatasi oleh satu pihak atau pemerintah saja, seluruh warga Negara dan pihak-pihak yang terkait harus berpartisipasi dalam mengatasi masalah ini agar diperoleh hasil yang diinginkan. Cara yang bisa dilakukan antara lain : dengan membuat alat pengolah limbah, penimbunan (alokasi) bahan pencemar di tempat yang aman, dan daur ulang limbah. Selain itu, mengingat demikian luas laut kita maka salah satu cara penanggulangan pencemaran di laut adalah dengan upaya pencegahan seperti: kegiatan berupa pelarangan dan pencegahan, kegiatan pengendalian dan pengarahan.

\section{Kesimpulan}

Konsentrasi logam zink pada air laut di wilayah pesisir pantai Mamboro yaitu berkisar antara $0,109 \mathrm{mg} / \mathrm{L}-0,155 \mathrm{mg} / \mathrm{L}$. Konsentrasi tersebut lebih tinggi jika dibandingkan dengan NAB logam seng yaitu $0,01 \mathrm{mg} / \mathrm{L}$. Untuk konsentrasi logam timbal yaitu berkisar antara $0,35 \mathrm{mg} / \mathrm{L}-0,433 \mathrm{mg} / \mathrm{L}$, konsentrasi tersebut lebih tinggi jika dibandingkan dengan $\mathrm{NAB}$ logam timbal yaitu $0,025 \mathrm{mg} / \mathrm{L}$.

\section{Ucapan Terima Kasih}

Penulis mengucapkan terima kasih kepada kepala laboran laboratorium Agroteknologi FAPERTA dan semua pihak yang telah membantu dalam pelaksanaan penelitian ini.

\section{Referensi}

Amriani. (2011). Bioakumulasi logam berat timbal (pb) dan seng ( $\mathrm{Zn}$ ) pada kerang darah (Anadara granosa L.) dan kerang bakau (Polymesoda bengalensis L.) di perairan Teluk Kendari. Tesis. Universitas Diponegoro

Bangun, J. M. (2005). Kandungan logam berat timbal $(\mathrm{Pb})$ dankadmium $(\mathrm{Cd})$ dalam air, sedimen dan organ tubuh ikan sokang (triacanthus nieuhofi) di perairan Ancol, teluk Jakarta. Skripsi. Semarang: Fakultas Perikanan Institut Pertanian Bogor.

Begum, A., Harikrishna, \& Khan, I. (2009). Analysis of heavy metals in water, sediments and fish samples of Madivala Lakes of Bangalore, Karnataka. International Journal of ChemTech Research CODEN( USA): IJCRGG, 1(2), 245-249.

Bozkurt, E., ELiri, O., \& Kesiktasi, M. (2014). Analysis of heavy metals in seawater samples collected from beaches of Asian side of Istanbul. Journal of Recreation and Tourism Research (jrtr), 1(1), 39 - 47.

Deswati, Suyani, H., \& Chairini, N. (2013). Studi optimasi penentuan seng secara voltammetri stripping adsorptif (AdSV). Jurnal Kimia Unand, 2(1), 98 - 106.

Effendi, H. (2003). Telaah kualitas air. Yogyakarta: Kanisius.

Fismawati. (2010). Analisis logam berat krom $(\mathrm{Cr})$ dan timbal $(\mathrm{Pb})$ dalam sedimen muara sungai Palu. Skripsi. Palu: Universitas Tadulako.

Hamzah, F., \& Saputro, P. D. (2013). Pola sebaran logam berat dan nutrien pada musim kemarau di estuari Perancak Bali. Jurnal Segara, 9(2), 85 - 165.

Herman, D. Z. (2006). Tinjauan terhadap tailing mengandung unsur pencemar arsen $(\mathrm{As})$, merkuri $(\mathrm{Hg})$, timbal $(\mathrm{Pb})$, dan kadmium $(\mathrm{Cd})$ dari sisa pengolahan bijih logam. Jurnal Geologi Indonesia, 1(1), 31 36.

Ika. (2012). Analisis logam timbal (Pb) dan besi $(\mathrm{Fe}$ ) dalam air laut di wilayah pesisir pelabuhan ferry Taipa kecamatan Palu Utara. Skripsi. Palu: Universitas Tadulako. 
Kacaribu, K. (2008). Kandungan kadar seng $(\mathrm{Zn})$ dan besi $(\mathrm{Fe})$ dalam air minum dari depot air minum isi ulang air pegunungan Sibolangit di kota Medan. Tesis. Medan: Universitas Sumatera Utara.

Marasabessy, M. D., Edward, \& Valentin, F. L. (2010). Pemantauan kadar logam berat dalam air laut dan sedimen di perairan pulau Bacan, Maluku Utara. Jurnal Sains, 14(1), 32-38.

Maslukah, L. (2006). Konsentrasi logam berat $P b, C d, C u, Z n$ dan pola Sebarannya di muara banjir kanal barat. Tesis. Semarang: pada Institut Pertanian Bogor.

Ni'matuzahroh, Yachya, \& Tanjung. (2006). Penanganan logam berat dengan mikroorganisme atau mikrobia (bioakumulasi, bioremediasi, atau bioremoval). Jurnal Hayati, 12(1), 13 - 18.

Rahman, A. (2006). Kandungan logam berat timbal $(\mathrm{Pb})$ dan kadmium (Cd) pada beberapa jenis Krustasea di pantai Batakan dan Takisung Kabupaten Tanah Laut Kalimantan Selatan. Jurnal Bioscientiae, 3(2), 93-101.

Rochyatun, E., Kaisupy, T., \& Rozak, A. (2006). Distribusi logam berat dalam air dan sedimen di perairan muara sungai Cisadane. Jurnal Sains, 10(1), 35 - 40.

Ruslan. (2008). Penentuan kapasitas pengompleks dan konstanta stabilitas kondisional logam berat tembaga dalam air sungai Palu. Jurnal Marina Chimica Acta, 1(2), 6-10.

Siaka, I. M. (2008). Korelasi antara kedalaman sedimen di pelabuhan Benoa dan konsentrasi logam berat $\mathrm{Pb}$ dan $\mathrm{Cu}$. Jurnal Kimia, 2(2), 61-70.

Stancheva, Makedonski, \& Petrova. (2013). Determination of heavy metals $(\mathrm{Pb}, \mathrm{Cd}, \mathrm{As}$ And $\mathrm{Hg}$ ) in black sea grey mullet (mugil cephalus). Bulgarian Journal of Agricultural Science, 19(1), 30-34.

Sudarmaji, Mukono, J., \& Corie. (2006). Toksikologi logam berat b3 dan dampaknya terhadap kesehatan. Jurnal Kesehatan Lingkungan, 2(2), 129 -142.

Suprapti, N. H., Syárani, L., \& Anggoro, S. (2012). The chromium (Cr) content in water and in the tissue of mud crab (scylla serrata forskal.) in the brackishwater ponds around babon river estuary of Semarang coastal areas in Central Java Indonesia. Journal of Coastal Develpopment, 16(1), 6267.

Tarigan, Z., Edward, \& Rozak, A. (2003). Kandungan logam berat $\mathrm{Pb}, \mathrm{Cd}, \mathrm{Cu}, \mathrm{Zn}$ dan Ni dalam air laut dan sedimen di muara sungai Membramo Papua dalam kaitannya dengan kepentingan budidaya perikanan. Jurnal Sains, 7(2), 119 - 127. 